\title{
Staphylococcus simulans
}

National Cancer Institute

\section{Source}

National Cancer Institute. Staphylococcus simulans. NCI Thesaurus. Code C86773.

A species of facultatively anaerobic, Gram positive, cocci shaped bacteria in the phylum

Firmicutes. This species is positive for catalase and urease and negative for oxidase,

alkaline phosphatase and coagulase. It can ferment sucrose, mannitol, fructose, and

lactose but not arabinose, cellobiose, turanose, xylose, or xylitol. S. simulans is found on

human and animal skin and is a pathogen that can cause bumble foot disease and

mastitis in animals and ostomyelitis and prosthesis related infections in humans. 